\title{
Guest House For Young Widows - Among the
}

\section{Women of ISIS}

Azadeh Moaveni (2019), Guest House For Young Widows - Among the Women of ISIS, Melbourne: Scribe Publications,

352pp, ISBN: 9781526607423 (hardback)

338pp, ISBN: 9781925849608 (paperback)

\section{Helen Stenger, Monash University, Australia}

Guest House for Young Widows follows 13 women on their pathway in and out of ISIS. Azadeh Moaveni illuminates the women's stories by providing insights into their biographies and personal background, shedding light on their thoughts and feelings, while simultaneously putting their experiences into a local and international political context.

The book is structured into 5 main parts with 40 chapters as well as a prologue and an epilogue. At the beginning of the book, the grievances and struggles of the women living in Tunisia, Syria, Germany and London are described. Moaveni follows the lives of urban women from a variety of backgrounds: some are still in school, some have university degrees; some are young teenagers while others are middle-aged; some are secular, others are religious. Narrating the upbringing and experiences of the women places them in a wider context. For example, she describes what it was like to be a young woman in the Salafi movement in the aftermath of the Tunisian uprising, a university student from a modern household in Damascus, and how being a Muslim convert from a working-class background in Frankfurt influenced a young woman's life choices. By portraying these vastly different pathways to joining ISIS, the author showcases the diversity of the female recruit's motivations.

Moaveni illustrates how the women reached their individual decisions to join ISIS. While we may denounce the pathway they chose, this illustration allows us to understand their agency and humanity. She also provides details about the women's travel into ISIS-held territory in Syria and Libya - the 'caliphate'. Once the narrative is inside the 'caliphate', 
Moaveni explores the different roles the women took on, which ranged from working for the moral police to becoming a housewife waiting for the husband to return from the battlefield.

She introduces the 'guesthouse' for widows - which is a place where all single and widowed women are staying - and outlines the pressure on the women to remarry. Within this context, Moaveni also explains the colonial and racialised hierarchies within ISIS, among both foreign fighters and the local population. The latter group often viewed foreigners 'as colonizers' (p. 187). Towards the final chapters, Moaveni examines how the women - to varying degrees - became increasingly critical of the organisation over time and how some of the women fled or tried to flee ISIS-held territory.

Throughout the book, Moaveni stresses the roles of Western colonialism, the War on Terror and Islamophobia, and how they fuel extremism. Western counter-terrorism measures are critically scrutinised since they typically fail to engage with these wider structural factors. The Islamophobic narrative and reluctance to understand the specific experiences of Muslim women in a Western context are particularly illustrated in the author's retelling of the Bethnal Green Girls' story - where four teenagers joined ISIS from Bethnal Green, London. The failure of counter-terrorism measures to engage with the grievances of young women drawn to ISIS is also demonstrated in Moaveni's examination of Tunisia, where discriminatory practices in prisons leave vulnerable women radicalised.

Guest House for Young Widows is a notable contribution to current debates surrounding women's involvement in terrorism, highlighting an intersectional perspective that considers gender, class, race, religion, age and ethnicity. Moaveni used primary and secondary data to write this book, including academic literature, policy documents, media articles and interviews. For this, she travelled to Tunisia, Syria, Turkey and the UK to gain a deeper understanding of the women's pathways. A methodological strength of the book is that Moaveni reflects on her own positionality during the investigative research. She discusses how her identity markers allowed her to blend in physically as well as how having religious literacy helped her with the research. Moreover, she explains that she felt close to some of her interviewees at times, saying that she 'could hear her adolescence' (p. 334). This approach - to reflect upon one's own identity, positionality and their power dynamics - is not only honest and brave but unique within terrorism literature. 
Reinyention: an International Journal of Undergraduate Research 13:2 (2020)
In conclusion, the book achieves its goal of encouraging the reader to 'understand' why some women joined ISIS. It makes 'terrorism' both personal and tangible, even relatable, without justifying the women's choices. In this balancing act, Moaveni shows how it is possible to be a collaborator in terrorism and a victim at the same time. I recommend Guest House for Young Widows to policymakers, scholars and practitioners as well as everyone who is curious about why women from all over the world have been drawn to a misogynist terrorist organisation such as ISIS.

\section{Alicja Lysik, Monash University}

The insightful report that originated from The New York Times takes the reader on a gripping journey through Tunisia, England and France, among other places, showcasing the stories of 13 women, who for various reasons have left their homes to join ISIS in Syria. The book by Azadeh Moaveni is divided into five parts, where each part represents a different stage in the respective subjects' life. As a result, step by step, we have the opportunity to meet the young women, their family and friends, as well as glimpse into the environment surrounding them.

Azadeh Moaveni at no point of this book imposes compassion on the reader, which I personally found to be one of its biggest assets. The inquisitive reporting provides an opportunity to form your own opinion, based on the real-life stories of the young women, and on the prepossessed knowledge on the topic. Moaveni seems to be filling a gap as she injects a much-needed perspective in the sea of sensation-seeking publications. The journey that the reader experiences by diving into this story gives space to understand the background of the women's decisions, rather than merely to judge them as 'female jihadists' - a term most often used in the Western media. I also found it very compelling that Moaveni explicitly notes that many of the stories told by the subjects could be an attempt to portray themselves in a certain way (p. 332). One could argue, most likely justifiably, that this affects the credibility of the book. However, I believe that this is a given when it comes to interview-based reports.

Guest House for Young Widows eloquently shows that there is simply no single reason that prompted these women and young girls to make the decision to join the Islamic State. The reader follows how their initially different lifestyles start blending into seemingly the same story - of a woman who marries an ISIS fighter; he dies and becomes 
a martyr; she then becomes a young widow, often to marry another fighter and

eventually become a widow again. The strength of this book is also rooted in the variety of backgrounds that the female protagonists come from - some being fresh Islam converts like Dunya from Frankfurt, while some coming from traditional yet nonconservative families like Ghoufran and Nour from Tunisia. Sadly, the only voices that seem to be lacking from the story are those of hard-line female adherents of jihad, although this might be dictated, as the author mentions, by lack of the possibility to have a fully honest conversation inside the camps where most of the interviews had taken place (pp. 333-35).

In a very convincing way, Moaveni intertwines feelings and subjective observations with a factual political background, academic commentary and the socio-economic situation of the respective places. Throughout, the author draws on historical events of the region such as the Arab Spring, War on Terror or political struggles in Tunisia. All of the information combined gives the reader a well-rounded foundation to be able to fully understand the wider context and its implications. At the same time, the recurring theme of the Internet and social media reminds us of the contemporary nature of the stories. Understandably, this is an important thread as a lot of recruiting - especially in Western countries - happens through platforms such as Tumblr, Twitter, Facebook and WhatsApp. The author aptly describes this process when talking about one of the book's subjects: 'Sharmeena stumbled across, or was pushed into, a whole new world online' ( $p$. 109). A world where she read about atrocities committed towards Muslims, about the need for the emergence of the caliphate and about the misunderstanding of Islam by many politicians and news outlets. However, what I found most striking was that there was a lot of exchange between women, young muhajirats (female migrants), who gave their diary-like testaments about life in the caliphate, which for many women was a final push to travel to Syria (for example pp. 110-13). The book also analyses how social media was utilised by the police - for instance, old Facebook posts being used during investigations (p. 289). Throughout all of the stories, social media seems to be always somewhere in the background - whether it is communicating with husbands on the battlefield, arranging the travel to - or an escape from -Syria, to watching YouTube videos of famous Arabic pop stars.

Finally, the amount of information the reader receives comes with certain strings attached; namely, it is sometimes difficult to follow all of the threads as you come back 
to the same character after several dozen pages. This may, at times, make the story come across as disjointed, but this is a rather minor issue when you carefully follow the plot (or shall I say 'plots'?).

Guest House for Young Widows is a carefully crafted account based on years of reporting; countless hours of conversations, researching historical backgrounds and reaching out to many people who often responded with silence. The book is a must-read for those who already have an opinion on the topic, and those who are yet to form one.

To cite this paper please use the following details: Stenger, H. OR Lysik, A. (2020), Azadeh Moaveni (2019), 'Guest House For Young Widows - Among the Women of ISIS', Reinvention: an International Journal of Undergraduate Research, Volume 13, Issue 2, https://reinventionjournal.org/article/view/717/. Date accessed [insert date]. If you cite this article or use it in any teaching or other related activities please let us know by emailing us at Reinventionjournal@warwick.ac.uk. 